BARBARA J. SMITH

\title{
Background Characteristics and Education Needs of a Group of Instruction Librarians in Pennsylvania
}

This paper summarizes a study conducted on a group of instruction librarians in Pennsylvania to describe their backgrounds and determine their perceptions regarding the adequacy of their preparation and their needs for additional training. The study revealed: (1) over 60 percent of the group has taken credit courses dealing with instruction; (2) the majority is trained as reference librarians and works in that area now; (3) they are professionally active and read appropriate journals; (4) they participate in appropriate continuing education activities; (5) they see previous teaching experience as important; and (6) they feel they are adequately prepared, but see benefit from additional education.

A

SURVEY WAS CONDUCTED in the spring of 1980 as part of a doctoral dissertation to determine education and training characteristics of a group of instruction librarians at selected colleges and universities in Pennsylvania. ${ }^{1}$ The chief library administrators at these institutions were contacted; they identified a population of 145 librarians involved in bibliographic instruction. A questionnaire was mailed to these librarians. Of the librarians who returned the questionnaire, 12 did not meet the minimum requirements of an MLS degree and two years' instruction experience, producing a sample of 133 and yielding 120 eligible completed questionnaires and a response rate of 90 percent. Many of these librarians took the time to comment on the survey, reflecting professional commitment and a lively interest in bibliographic instruction.

Thirty-nine questions concerning the edu-

Barbara J. Smith is assistant dean, University Libraries, Pennsylvania State University, University Park. cation and training of these librarians, as well as their perceptions regarding the adequacy of their preparation, and their needs for additional training, produced data to answer the objectives of the study. These objectives were:

1. to determine if librarians engaged in bibliographic instruction received education and training, particularly in learning theory, teaching methodology, and/or instructional development;

2 . to determine how and when education, training, and experience related to bibliographic instruction were gained;

3 . to identify education and training needs of bibliographic instruction librarians as perceived by the population;

4. to gather limited demographic information about the population; and

5. to identify associations between the background of the respondents and their perceptions regarding (a) their need for further education and training, and (b) the adequacy of their backgrounds when they first engaged in bibliographic instruction.

Several assumptions were made in design- 
ing the study: (1) credit course work in learning theory, teaching methodology, or instructional development (comprehensive curriculum development and evaluation), coupled with the MLS degree constitute appropriate background to engage in bibliographic instruction; (2) two years' experience in bibliographic instruction is sufficient to permit the librarians involved to make judgements as to whether their preparation was adequate; (3) concentration in reference work in an MLS program, or assignment to reference duties implies an awareness of bibliographic instruction concerns; (4) membership and activity in professional library and education organizations imply an awareness of bibliographic instruction programs and their problems; and (5) regular reading of library and education journals implies an awareness of bibliographic instruction and the problems associated with it.

The academic institutions involved in the study were selected to include a contained geographical area with the assumption that close proximity would ensure an adequate response rate. And although the institutions are public, they offer the full range of academic programs, from two-year associate degrees to doctoral degrees, and are involved in continuing education programs as well, providing a diverse environment for bibliographic instruction. Location enrollments range from 300 to 32,000 . These institutions were chosen, also, because their libraries were known to offer bibliographic instruction to their students.

Responses represent all institutions involved. Descriptive statistics and crosstabulations on selected questionnaire responses were employed in analyzing the data.

Several studies have considered the education of academic librarians, but few have attempted to describe the background of instruction librarians. One exception is a study conducted by Roberts in 1978 concerning credit course instruction at ten State University of New York campuses; ${ }^{2}$ the librarians described are an elite group involved in credit instruction only, however. Bits and pieces of descriptions of instruction librarians are contained in several surveys and directories compiled by various state and regional organizations, but none reviewed is particularly comprehensive.

\section{Findings}

These librarians are not young. As table 1 shows, less than 3 percent are under thirty; more than half are forty or older; more than one-quarter are fifty or older. They have considerable experience. Seventy-five percent have been involved in bibliographic instruction for six or more years; nearly a third for twelve or more years. As expected, given the ages of these librarians, they earned their professional degrees some years ago. Seventy-six percent received the MLS degree ten or more years ago; nearly half earned their degrees ten to fourteen years ago. Ninety-one percent of these librarians are assigned to instruction activities less than halftime. Thirty-nine percent of the respondents hold or are working toward a second master's degree; 15 percent hold or have in progress a doctoral degree.

TABLE 1

\section{Selected Demographic Characteristics} $(N=120)$

\begin{tabular}{lrr}
\hline \hline Characteristic & Frequency & Percent \\
\hline Sex: & & \\
Male & 46 & 39 \\
Female & 72 & 61 \\
No response & 2 & - \\
Age: & & \\
$20-29$ & 4 & 38 \\
$30-39$ & 45 & 32 \\
$40-49$ & 38 & 26 \\
50 or older & 31 & - \\
No response & 2 & 5 \\
Years since MLS degree earned: & & 19 \\
$0-4$ & 6 & 47 \\
$5-9$ & 23 & 15 \\
10-14 & 56 & 14 \\
15-19 & 18 & \\
20 or more & 17 &
\end{tabular}

Years assigned to bibliographic instruction:

$\begin{array}{lcr}0-2 & 8 & 7 \\ 3-5 & 21 & 18 \\ 6-8 & 27 & 22 \\ 9-11 & 27 & 22 \\ 12 \text { or more } & 37 & 31\end{array}$

Bibliographic instruction assignment: *

Full-time $\quad 3 \quad 3$

Half-time 8

Less than half-time $\quad 109$

Graduate degrees held: MLS $\dagger$

99

$120-100$

Additional master's $\quad 47 \quad 39$

Doctorate 18

Note: Rounding errors account for column totals $\gtrless 100$ percent.

"Ninety-eight percent of the librarians are full-time employees.

$\uparrow$ Individuals not holding this first professional degree were eliminated from the study. 
Formal education and training in appropriate areas are present in the backgrounds of a majority of these librarians. As table 2 shows, 61 percent indicated they had taken a credit course in learning theory, teaching methodology, or instructional development; 52 percent did so while earning their undergraduate degrees. Only 17 percent indicated they received such education and training as part of the course work in their MLS degree programs. Only 13 percent indicated course work related to instruction was part of a second master's degree, 4 percent as part of a doctoral degree.

Indications of education and training of a general nature related to bibliographic instruction are set out in the data in table 3. Only 12 percent of the respondents participated in appropriate in-service training programs, which is more a negative comment on the libraries than the librarians involved. It is interesting to see that fully 55 percent of the respondents concentrated in reference work while pursuing their professional degrees. The amount of self-education as measured by journal reading is considerable. Ninety-eight percent of these librarians regularly read one or more library journals. Fifty-nine percent regularly read one or more education journals. (Regular reading was defined in the questionnaire as reading every issue of a journal.) Many continue to build their backgrounds by participating in instructionrelated continuing education activities. The data show that 54 percent participated in one or more such activities in the past two years.

The amount of related experience and professional activity is also considerable, as shown in the data displayed in table 4 .

\section{TABLE 2}

Credit Course Work in

Learning Theory, Teaching Methodology, OR INSTRUCTIONAL DEVELOPMENT

$$
(N=120)
$$

\begin{tabular}{lcc}
\hline Course Work & Frequency & Percent \\
\hline Undergraduate degree & 62 & 52 \\
Master's degree in library & 20 & 17 \\
$\quad$ science & 16 & 13 \\
Additional master's degree & 5 & 4 \\
Doctoral degree & & \\
Degree and nondegree & 73 & 61 \\
\hline course work* &
\end{tabular}

$\cdot N=119$.
TABLE 3

InStruction-Related Education and Training $(N=120)$

\begin{tabular}{lcc}
\hline Type of Education and Training & Frequency & Percent \\
\hline $\begin{array}{l}\text { In-service programs* } \\
\text { MLS degree }\end{array}$ & 14 & 12 \\
concentration: $\dagger$ & & \\
$\quad$ Acquisitions & 0 & 0 \\
Administration & 4 & 3 \\
Cataloging & 2 & 2 \\
Reference & 65 & 55 \\
Other & 20 & 17 \\
No concentration & 28 & 24 \\
No response & 1 & -
\end{tabular}

Self-education as indicated by number of library journals read:

$\begin{array}{lrr}0 & 3 & 3 \\ 1 & 8 & 7 \\ 2 & 25 & 21 \\ 3 \text { or more } & 84 & 70\end{array}$

Self-education as indicated by number of education journals read:

$\begin{array}{lll}0 & 50 & 42 \\ 1 & 27 & 23 \\ 2 & 18 & 15 \\ 3 \text { or more } & 25 & 21\end{array}$

Number of continuing education activities in past two years:

\begin{tabular}{lll}
0 & 56 & 47 \\
1 & 16 & 13 \\
2 & 18 & 15 \\
3 & 15 & 13 \\
4 or more & 15 & 13 \\
\hline
\end{tabular}

Note: Rounding errors account for column totals $>100$ percent.

$\bullet N=119$.

tConcentration in reference is the only response indicating appropriate background was received.

Twenty-eight percent of the respondents have taught credit courses in bibliographic instruction; 23 percent had college level teaching experience before they became involved in bibliographic instruction; and 47 percent had prior elementary- or secondarylevel teaching experience. Over half of the respondents have the major part of their noninstruction time assigned to the complementary area of reference work. Table 4 also shows that only 14 percent of the respondents have published, and that less than onequarter have engaged in studies dealing with bibliographic instruction. These librarians are involved in professional organizations to a large degree, however. Seventy-nine percent indicated membership in two or more professional library organizations; 32 percent in two or more professional education organizations. Forty-one percent held office in a library organization in the past two 
TABLE 4

Related Experience and Professional Activity

$(N=120)$

\begin{tabular}{|c|c|c|}
\hline Experience or Activity & Frequency & Percent \\
\hline Taught credit courses in bibliographic instruction & 33 & 23 \\
\hline Complementary noninstruction assignment in reference work ${ }^{*}$ & 62 & 52 \\
\hline College level teaching experience & 28 & 23 \\
\hline Elementary-or secondary-level teaching experience $\dagger$ & 56 & 47 \\
\hline Articles published or accepted & 17 & 14 \\
\hline Studies conducted or in progress* & 29 & 24 \\
\hline \multirow{2}{*}{\multicolumn{3}{|c|}{$\begin{array}{l}\text { Professional organization activity in past two years: } \\
\text { Library organization membership }\end{array}$}} \\
\hline & & \\
\hline $0-1$ & 26 & \\
\hline $2-3$ & 68 & 57 \\
\hline $4-5$ & 21 & 18 \\
\hline 6 or more & 5 & 4 \\
\hline \multicolumn{3}{|l|}{ Library organization office held } \\
\hline Yes & 47 & 41 \\
\hline No & 69 & 58 \\
\hline Not a member & 2 & 2 \\
\hline \multicolumn{3}{|l|}{ Education organization membership } \\
\hline $\begin{array}{l}0-1 \\
2-3\end{array}$ & $\begin{array}{l}82 \\
29\end{array}$ & $\begin{array}{l}68 \\
24\end{array}$ \\
\hline $4-5$ & 8 & 7 \\
\hline 6 or more & 1 & 1 \\
\hline \multicolumn{3}{|l|}{ Education organization office held } \\
\hline Yes & 13 & 11 \\
\hline No & 84 & 70 \\
\hline Not a member & 23 & 19 \\
\hline
\end{tabular}

Note: Rounding errors account for column totals $>100$ percent.

$\bullet N=119$.

$\uparrow N=118$.

years; only 11 percent did so in an education organization.

The level of current continuing education activity is encouraging. As shown in table 5, 54 percent of the respondents indicated they participated in one or more such activities in the past two years. Nearly one third (30 per-

TABLE 5

Timing of Appropriate

EdUCATION AND Training

$(N=120)$

Activity Frequency Percent

Continuing education activities in the past two years:

\begin{tabular}{lcc}
0 & 56 & 47 \\
1 & 16 & 13 \\
2 & 18 & 15 \\
3 & 15 & 13 \\
4 or more & 15 & 13 \\
$\begin{array}{l}\text { Course work: } \\
\text { Before instruction }\end{array} \quad$ & \\
$\quad$ assignment & & \\
After instruction & 52 & 72 \\
$\quad$ assignment & & \\
Both & 9 & 13 \\
No response & 11 & 15 \\
\hline
\end{tabular}

Note: Rounding errors account for column totals $<100$ percent. cent) indicated they engaged in three or more related activities in the same time period. Although only seventy-two respondents (60 percent of the total group) reported they had taken credit courses in learning theory, teaching methodology, or instructional development, 72 percent of them indicated that this occurred before they were assigned to bibliographic instruction.

As shown in table 6, 54 percent of the librarians in this study reported they gained relevant education and training through selfstudy (commonly referred to as independent

\section{TABLE 6}

Perceptions of Primary Means By Which Appropriate Education and Training Were Gained $(N=120)$

\begin{tabular}{lcc}
\hline Means & Frequency & Percent \\
\hline Self-study & 63 & 56 \\
In-service programs & 1 & 1 \\
Conferences & 1 & 1 \\
Workshops & 2 & 2 \\
Credit courses & 34 & 30 \\
Other & 11 & 10 \\
No response & 8 & - \\
\hline
\end{tabular}


study). That only 3 percent indicated that conferences and workshops were the primary means of acquiring the background in question was unexpected. The data further show that 30 percent of the respondents saw credit courses as their primary means of preparation.

Several factors were identified which could influence whether or not librarians gained the necessary education and training. As the data in table 7 show, libraries continue as they have in the past; they make few demands on librarians to qualify for bibliographic instruction. ${ }^{3}$ Only 7 percent of the respondents indicated they had to meet any special requirements beyond the MLS degree to participate in an instruction program. Furthermore, only 12 percent indicated their libraries provided in-service training for them. Eighty percent of the respondents see their library administrations as supportive of bibliographic instruction programs yet only 19 percent indicated they received financial support for appropriate education and training. Of the twenty-three librarians who received financial support, 52 percent indicated the funding they received supported more than half of their expenses. It must be kept in mind that participation in bibliographic instruction programs continues to be part-time, however. The present study reinforces that belief; 91 percent of the responding librarians reported being assigned to instruction less than half time. It is important to note that 62 percent of the librarians in this study perceived themselves as adequately prepared initially to engage in bibliographic instruction.

Although 62 percent of these librarians indicated they felt they were adequately prepared to take on bibliographic instruction activities when they were first assigned to instruction (see table 7), the data in table 8 show that only 7 percent indicated they would not benefit from additional education and training. Forty-three percent chose instructional development as an area of need; nearly one third (32 percent) indicated additional work in teaching methodology would be beneficial, while only 9 percent felt that they needed additional work in learning theory.

Although professional organizations view their conferences as serving a major continuing education function, it is interesting to see that only 1 percent of the respondents saw conferences as the best means of providing education and training for bibliographic instruction. Twenty-eight percent viewed previous teaching experience as the best means

TABLE 7

FACtors AfFecting the ACQUisition OF Appropriate Education, Training, and ExpERIEnce

$(N=120)$

\begin{tabular}{lcc}
\hline Factor & Frequency & Percent \\
\hline $\begin{array}{l}\text { Presence of entry requirements } \\
\text { Presence of in-service programs* }\end{array}$ & 8 & 7 \\
Perception that administration is supportive* & 14 & 12 \\
Presence of administrative financial support for continuing education & 95 & 80 \\
$\quad$ activities* & 23 & 19 \\
$\begin{array}{l}\text { Amount of administrative financial support for continuing education } \\
\text { activities: }\end{array}$ & & \\
$\quad$ Less than half & 7 & 30 \\
$\quad$ Half & 4 & 17 \\
$\quad$ More than half & 97 & 52 \\
$\quad$ No response & 24 & - \\
Amount of personal funding for continuing education activities: & 4 & 38 \\
$\quad$ Less than half & 36 & 6 \\
$\quad$ Malf & 56 & 56 \\
$\quad$ Nore than half & 109 & 91 \\
Assigned less than & 62 & 52 \\
Major noninstruction assignment in reference* & ${ }^{*}$ & 62 \\
Perception that adequately prepared & 74 &
\end{tabular}

Note: Rounding errors account for column totals $<100$ percent.

$* N=119$. 
TABLE 8

Perceptions Related to Additional. Education and Training $(N=120)$

\begin{tabular}{lrr}
\hline \hline Perception & Frequency & Percent \\
\hline $\begin{array}{l}\text { Area of need: } \\
\text { Learning theory }\end{array}$ & 11 & 9 \\
Teaching & & \\
$\quad$ methodology & 38 & 32 \\
Instructional & & \\
$\quad$ development & 51 & 43 \\
Other & 10 & 8 \\
None needed & 8 & 7 \\
$\quad$ No response & 2 & - \\
Best means of preparation: & 8 & 7 \\
Self-study & & \\
In-service & 22 & 19 \\
$\quad$ programs & 1 & 1 \\
Conferences & 28 & 25 \\
Workshops & 20 & 18 \\
Credit courses & 2 & 2 \\
Other & & \\
Previous teaching & & \\
$\quad$ experience & 72 & 28 \\
$\quad$ No response & 7 & - \\
Best means of delivery of & & \\
future education and training: & & \\
Self-study & 6 & 5 \\
In-service & & \\
programs & 24 & 21 \\
Conferences & 5 & 4 \\
Workshops & 38 \\
Credit courses & 37 & 33 \\
Other & 3 & 3 \\
No response & 7 & - \\
\hline N & &
\end{tabular}

Note: Rounding errors account for column totals $<100$ percent.

to prepare, a perception supported in the literature. ${ }^{4}$ Twenty-five percent selected workshops. When asked what means of delivering appropriate education and training to librarians was best for the future, 34 percent indicated workshops, while 33 percent chose credit courses. These findings as summarized in table 8 compare favorably to a study on modes of delivery for continuing education conducted by Stone. ${ }^{5}$

As shown in table 9, there is evidence of a strong relationship between librarians' assessments that they were adequately prepared when first assigned to bibliographic instruction, and their assessment that their primary means of gaining appropriate knowledge and information was by having taken credit courses in learning theory, teaching methodology, or instructional development. Only 2 percent of instruction librarians who participated in appropriate course work saw themselves as inadequately prepared while the 32 percent who chose self-study methods viewed themselves as inadequately prepared. Self-study results in only an even chance of being prepared.

In table 10 , evidence of a positive relationship between (1) an assessment of having undertaken adequate preparation and (2) prior elementary or secondary teaching experience is shown. Of the 49 percent of instruction librarians who considered themselves prepared to engage in bibliographic instruction activities, 41 percent had had prior teaching experience. Those who indicated they saw themselves as inadequately prepared are nearly evenly divided between those with prior teaching experience and those with none. The results show that those who have had teaching experience tend to see themselves as prepared, however.

The data in table 11 suggest that those who indicated they had taken credit course work dealing with instruction are more likely to select instructional development as an area of need. Those who have not had such course work are more likely to select teaching methodology.

TABLE 9

Relationship between Assessment of Adequate Preparation and Primary Means of Preparation

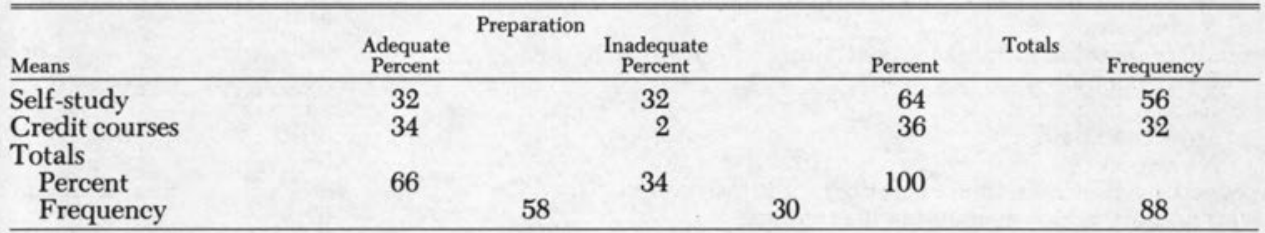

Note: Missing values $=8$.

Note: Cross-tabulations producing marginal frequencies of ten or less were deleted.

Note: $x^{2}=17.35 \quad d f=1 \quad p>.01$. 
The data in table 12 indicate that the presence of previous elementary- or secondaryschool teaching experience results in the choice of instructional development as an area for further education and training. Absence of prior teaching experience tends to result in an expression of need in teaching methodology.

\section{Discussion AND CoNCLUSIONS}

On the whole the librarians in this group have acquired education and training appropriate to their assignments. The education and training were not gained as part of their professional degree programs but were

TABLE 10

Relationship BETWEen AsSessment of Adequate Preparation and Elementary or Secondary SCHOOL Teaching Experience

\begin{tabular}{lccccc}
\hline \hline $\begin{array}{l}\text { Teaching } \\
\text { Experience }\end{array}$ & $\begin{array}{c}\text { Adequate } \\
\text { Percent }\end{array}$ & $\begin{array}{c}\text { Preparation } \\
\text { Inadequate } \\
\text { Percent }\end{array}$ & Percent & Totals & Frequency \\
\hline $\begin{array}{l}\text { Present } \\
\text { Absent }\end{array}$ & 41 & 27 & 68 & 73 \\
$\begin{array}{l}\text { Totals } \\
\quad \text { Percent }\end{array}$ & 8 & 23 & 31 & 34 \\
$\quad$ Frequency & 49 & 53 & 50 & 59 & 100 \\
\hline
\end{tabular}

Note: Missing values $=2$.

Note: Rounding errors account for total percent $<100$ percent.

Note: Cross-tabulations producing marginal frequencies of ten or less were deleted.

Note: $x^{2}=10.6 \quad d f=1 \quad p>.01$.

TABLE 11

RELATIONSHIP BETWEEN NEED FOR

Additional Education and Training and

Credit Course Work in Learning Theory, Teaching

METHODOLOGY, OR INSTRUCTIONAL DEVELopMENT

\begin{tabular}{lcccccc}
\hline Course Work & $\begin{array}{c}\text { Teaching } \\
\text { Methodology } \\
\text { Percent }\end{array}$ & Need & $\begin{array}{c}\text { Instructional } \\
\text { Development } \\
\text { Percent }\end{array}$ & Percent & Totals & Frequency \\
\hline Present & 19 & 37 & 56 & 50 \\
Absent & 24 & & 20 & 44 & 39 \\
Totals & 43 & 38 & 47 & 51 & 100 & \\
$\quad \begin{array}{l}\text { Percent } \\
\text { Frequency }\end{array}$ & 43 & & 51 & & 89 \\
\hline
\end{tabular}

Note: Missing values $=2$.

Note: Cross-tabulations producing marginal frequencies of ten or less were deleted.

Note: $x^{2}=3.53 \quad d f=1 \quad p<.01$.

TABLE 12

Relationship between NeEd for Additional

Education and Training and Prior Teaching Experience in Elementary or Secondary Schools

\begin{tabular}{|c|c|c|c|c|c|c|c|}
\hline Experience & $\begin{array}{c}\text { Teaching } \\
\text { Methodology } \\
\text { Percent }\end{array}$ & Need & $\begin{array}{c}\text { Instructional } \\
\text { Development } \\
\text { Percent }\end{array}$ & & Percent & Totals & Frequency \\
\hline Present & 12 & & 33 & & 45 & & 39 \\
\hline Absent & 32 & & 23 & & 55 & & 48 \\
\hline \multicolumn{8}{|l|}{ Totals } \\
\hline Percent & 44 & & 56 & & 100 & & \\
\hline Frequency & & 38 & & 49 & & & 87 \\
\hline
\end{tabular}

Note: Missing values $=4$.

Note: Cross-tabulations producing marginal frequencies of ten or less were deleted.

Note: $x^{2}=9.35 \quad d f=1 \quad p>.01$. 
gained in undergraduate degree programs, in credit courses, or by self-study. A test of association between means of preparation and adequacy of preparation revealed that taking credit courses is perceived to be a more effective means of preparation than self-study, however.

A majority of the librarians specialized in reference work in their professional training programs, which compares favorably with findings in the literature. ${ }^{6}$ They tend to belong to professional organizations; only 2 percent reported "not a member," which compares favorably to other findings. ${ }^{7}$

No record of instruction librarians' publishing and research activities is available. Because the librarians in this study work in an academic environment, a higher rate of activity was expected than the 15 percent response to a record of articles published or accepted for publication and the 25 percent indication of research activity.

A total of 98 percent indicated they read one or more library journals regularly; a total of 59 percent read education journals regularly. The evidence in the literature is not clear, but the response is somewhat higher than expected, especially for education journals. Perhaps this latter finding is explained by the fact that all institutions in the study are involved in teacher training. They did not attempt to update their instruction skills as much as expected, but 54 percent did participate in one or more continuing education activities in the past two years. In light of the fact that their instruction assignments are less than half-time, this record of activity should be viewed favorably.

The perception that teaching is the best means of preparation to engage in bibliographic instruction was supported. Fortyseven percent had prior elementary- or secondary-school teaching experience; 23 percent had prior college-level teaching experience. Seventy-five percent have been involved in bibliographic instruction six or more years. Only 28 percent reported having taught bibliographic instruction credit courses, however.

Although these librarians are assigned to instruction less than half-time, 52 percent of them have major assignments in reference work, an area of activity that is closely associated with instruction by the profession.
And although 76 percent of these librarians received their professional training ten or more years ago, before the recent decade of activity in bibliographic instruction, their record of training in their undergraduate degrees and elsewhere before their involvement in instruction appears to offset the fact that instruction had not been covered in their professional degree work.

Administrative support for the improvement of the skills of the librarians involved compares with the conclusions drawn in the literature: it is minimal. ${ }^{8}$ Administrators are willing to assign them to instruction but are not willing to find the funds to provide the opportunity for improving skills.

By and large these librarians feel they are prepared to carry out their instruction responsibilities, but they are nearly unanimous (only 7 percent not agreeing) in their perception that they could benefit from additional education and training in instruction-related areas. In particular they are interested in becoming more competent in instructional development (43 percent) and teaching methodology (32 percent).

Workshops, credit courses, and, to a lesser degree, in-service programs are seen by these librarians as the best means of acquiring appropriate additional education and training for themselves in the future.

\section{IMPLICATIONS}

Lack of specific administrative support for upgrading instruction librarians' skills is again demonstrated in this study. Bibliographic instruction programs and their improvement remain, apparently, labors of love for the librarians involved. It appears that the profession needs to reexamine its stance on instruction, given the evidence that library administrators do not support these programs in concrete terms. Espousing bibliographic instruction at conferences and in the literature while the workplace lacks specific continuing support frustrates the librarians and shortchanges the students.

The profession should take note that in this study the value of conferences is challenged. They are not perceived as' a useful means of providing continuing education in this area. This strikes at the heart of the profession's justification for holding conferences.

Again, the view that previous teaching ex- 
perience is the most effective means to prepare to teach is supported. Although the needs of bibliographic instruction programs are not being addressed by the library schools, ${ }^{9}$ if programs are developed to meet this need, teaching practicums should be an integral part of the requirements designed to assure competency for librarians who will be called upon to function as skilled professionals responsible for instruction.

\section{REFERENCES}

1. Barbara J. Smith, "Education and Training Characteristics of Librarians Engaged in Bibliographic Instruction in Eighteen Colleges and Universities in Pennsylvania" (D.Ed. dissertation, Pennsylvania State Univ., 1981).

2. Anne Roberts, A Study of Ten SUNY Campuses Offering an Undergraduate Credit Course in Library Instruction (Washington, D.C.: Council on Library Resources, 1978), ED 157529.

3. Sara L. Whildin, "Library Instruction in Pennsylvania Academic Libraries: A Survey Summary," PLA Bulletin 31:8 (Jan. 1976).

4. Roberts, "A Study."

5. Elizabeth W. Stone, Continuing Library and Information Science Education (Washington, D.C.: American Society for Information Science, 1974).

6. Roberts, "A Study."
7. Perry D. Morrison, The Career of the Academic Librarians: A Study of the Social Origins, Educational Attainments, Vocational Experience, and Personality Characteristics of a Group of American Academic Librarians (Chicago: American Library Assn., 1969), ACRL monograph no. 29.

8. Melissa Cain and Lois Pausch, Library Instruction Programs in Illinois Academic Libraries: A Directory and Survey Report (Chicago: Illinois Library Association, 1978). See also Patricia Senn Breivik, "Leadership, Management, and the Teaching Library," Library Journal 103:2045-48 (Oct. 15, 1978).

9. Vida Stanton, "The Library School: Its Role in Teaching the Use of the Library," in John Lubans, Jr., ed., Progress in Educating the Library User (New York: Bowker, 1978). 